\title{
In Vivo Administration of a PKA Type I Inhibitor (Rp-8-Br-cAMPS) Restores T-Cell Responses in Retrovirus-Infected Mice
}

\author{
Btissam Nayjib $^{\S, 1}$, Mustapha Zeddou ${ }^{\S, 1}$, Pierre Drion ${ }^{2}$, Jacques Boniver ${ }^{3}$, Kjetil Tasken ${ }^{4}$, \\ Souad Rahmouni, ${ }^{*}$, and Michel Moutschen ${ }^{1}$
}

\author{
${ }^{I}$ Immunology and Infectious Diseases Laboratory, GIGA-Research, B34, University of Liège-CHU Liège, 4000 Liège, \\ Belgium \\ ${ }^{2}$ Animal Facility, GIGA-Research, B23, University of Liège, 4000 Liège, Belgium \\ ${ }^{3}$ Department of Pathology, GIGA-Research, University of Liège-CHU Liège, 4000 Liège, Belgium \\ ${ }^{4}$ Biotechnology Centre of Oslo, University of Oslo, P.O. Box 1125, Blindern, 0317 Oslo, Norway and Lauras AS, \\ Gaustadalléen 21, N-0349 Oslo, Norway
}

\begin{abstract}
Murine AIDS (MAIDS) is caused by infection with the murine leukemia retrovirus RadLV-Rs and is characterized by T-cell anergy and severe immunodeficiency with increased susceptibilty to several experimental opportunistic infections as observed in HIV infection. T cell anergy is associated with an increase of intracellular cAMP level, triggering a multistep pathway involving activation of PKA type I and resulting in inhibition of proximal TCR signaling. We have previously demonstrated that blocking PKA type I using the selective inhibitor Rp-8-Br-cAMPS, restores T-cell function in vitro in MAIDS as well as in HIV infection. In the present report, we investigated the effect of parenteral administration of Rp-8-Br-cAMPS in mice with MAIDS. We show that the compound is not toxic and partially restores the ex vivo proliferative responses to anti-CD3 $\mathrm{mAb}$, but that it has no effect on the lymphadenopathy and splenomegaly characterizing the MAIDS syndrome.
\end{abstract}

\section{INTRODUCTION}

HIV infection is associated with several abnormalities of signal transduction which involve infected as well as noninfected T-cells. Such defects persist even after long periods of viral suppression and hamper restoration of immune responses against pathogens including HIV itself. An increased level of intracytoplasmic cyclic AMP (cAMP) has previously been observed in T cells of HIV infected patients. Increased cAMP participates in the impairment of T-cell receptor (TCR) signaling through a PKA type I/Csk pathway $[1,2]$ but nuclear translocation of the catalytic subunit of PKA type I has also been observed in MAIDS [8]. Therefore the cAMP/PKA type I pathway could also inhibit more distal steps of TCR signaling through CREM phosphorylation and IL-2 secretion blockade as demonstrated in lupus erythematosous [9].

Treatment of HIV-infected patients with inhibitors of cyclooxygenase 2 (COX-2), which limit exposure of $\mathrm{T}$ cells to $\mathrm{PGE}_{2}$ (a cAMP-inducing agent) in the lymphoid organs also allows partial restoration of $\mathrm{T}$ cell function [4]. Since other mediators than $\mathrm{PGE}_{2}$ can increase the concentration of intracytoplasmic cAMP, pharmacological agents acting downstream of cAMP (i.e. at the PKA type I level itself) could potentially allow for a more complete restoration of TCR signalling. Rp-8-Br-cAMPS (8-Bromoadenosine-3', 5'monophosphorothioate, $\mathrm{Rp}$ - isomer) is an analog of cAMP which occupies cAMP binding sites on the regulatory subunit

*Address correspondence to this author at the Immunology and Infectious Diseases Laboratory, GIGA-Research, B34, University of Liège-CHU Liège, 4000 Liège, Belgium; Tel: +32 4366 2482; Fax: +32 4366 4534; E-mail: srahmouni@ulg.ac.be

${ }^{\S}$ These two authors contributed equally to this work. of PKA type I and prevents dissociation and thus activation of the kinase holoenzyme [6]. In vitro, Rp-8-Br-cAMPS strongly improves the function of T cells isolated from HIV infected patients (even with optimal viral suppression) [1, 4, 7] and from mice with RadLV-Rs murine AIDS (MAIDS) [8]. MAIDS is characterized by a profound anergy of T cells which causes severe opportunistic infection similar to what is observed in HIV infection [10]. In MAIDS, T cells, especially those belonging to the CD4 subset, display a major increase of cAMP concentration which abolishes TCR signaling by a mechanism also operative in human $\mathrm{T}$ cells $[8$, $11,12]$. Once full-blown MAIDS is installed, very few therapeutic approaches have been shown to restore, at least partially, T cell function.

In the present report, we investigated the effect of Rp-8Br-cAMPS administrated parenterally during 10 days on lymphadenopathy, splenomegaly and $\mathrm{T}$ cell anergy which are the main features of MAIDS.

\section{MATERIAL AND METHODS}

\section{Mice and Cell Suspension}

Male C57BL/6 mice were bred in our facility. Mice were injected twice intraperitoneally (i.p.) at the age of 4 and 5 weeks with $0.25 \mathrm{ml}$ of the cell free viral extract. Agematched control mice were injected twice i.p. with $0.25 \mathrm{ml}$ phosphate buffered saline (PBS). At different times post infection, mice were killed by $\mathrm{CO}_{2}$ asphyxiation. Peripheral lymph nodes (inguinal, axillary and cervical) were dissociated with syringes to obtain single cell suspensions and passed through a nylon cell strainer, washed three times with complete RPMI 1640 medium and counted on Thoma cytometer after trypan blue exclusion prior to further analysis 
or cell culture. For in vivo experiments, Rp-8-Br-cAMPS 1 $\mathrm{mg}$ qd was injected i.p. to the mice during 10 days. In initial experiments aimed at evaluating $\mathrm{Rp}$-8-Br-cAMPS biodistribution, groups of infected and healthy mice were treated by subcutaneous implantation of Alzet osmotic pumps (Cupertino, CA) filled with $10 \mathrm{mg} \mathrm{Rp}-8$-Br-cAMPS dissolved in PBS and set to deliver $0.7 \mathrm{mg} / 24 \mathrm{~h}$. The pumps were implanted 14 days before sacrifice. All studies on mice with MAIDS were conducted under a license delivered to the University of Liege animal facility by the Ministry for Agriculture and with permission from the Local Animal Ethics Committee.

\section{Virus}

Viral extract was prepared from lymph nodes of mice injected 2 months earlier with RadLV-Rs as described previously [12]. Lymph nodes were collected, ground in PBS and centrifuged twice at $1.5 \times 10^{4} \mathrm{~g}$ for $30 \mathrm{~min}$. This acellular viral extract was stored in liquid nitrogen. XC plaque assay was used as previously described $[8,13]$ for quantification, and showed that the viral preparation contained $10^{3}$ particle forming units (PFU) of ecotropic virus $/ \mathrm{ml}$.

\section{Reagents and Antibodies}

Anti-CD3 mAb (145-2C11) used to activate $\mathrm{T}$ cells was from Tebu-bio (Tebu-bio nv, Boechout, Belgium). Rp-8-BrcAMPS (LA1001) was produced by Biolog (Bremen, Germany) for Lauras AS.

\section{Quantitative Determination of Rp-8-Br-cAMPS Concen- tration}

Suitable sample preparation and HPLC methods were developed for quantitative determination of Rp-8-Br-cAMPS in mice tissues and serum samples that allows evaluation of drug concentrations of in vivo experiments (by BioLog Gmbh, Bremen, Germany for Lauras AS). Calibrations were done with $\mathrm{Rp}-8$-Br-cAMPS and 8-Br-cAMP. Both compounds gave sufficient linearity in a range between $0 \mathrm{ng} / \mathrm{ml}$ and $1000 \mathrm{ng} / \mathrm{ml}$. Each mice sample was transferred into a borosilicate micro mortar $(1000 \mu \mathrm{L})$ followed by addition of $250 \mu 1$ water. After manual homogenization and addition of $750 \mu 1$ water the resulting suspension was transferred into $1,5 \mathrm{~mL}$ sarstedt-tubes with screw cap. After a minimum period of 4 hours at $-70{ }^{\circ} \mathrm{C}$ all samples were freeze-dried in a Speed-Vac under oil-pump vacuum overnight. The freezedried material was suspended in $1000 \mu \mathrm{L} \mathrm{MeOH} / \mathrm{H}_{2} 0$ $(1: 1 ; \mathrm{V} . \mathrm{v})$ and placed for $15 \mathrm{~min}$ in an ultrasonic bath, followed by centrifugation for 15 min (Heraeus; Biofugeprimo; $13000 \mathrm{rpm}$ ). $0.85 \mathrm{~mL}$ of the supernatant was loaded on an anion exchanger SPE cartridge (Chromafix 400mg SB/ArtNr.: 731835/Machery-Nagel), washed twice with $2 \mathrm{ml}$ of water and then eluted with $1 \mathrm{ml} 0,6 \mathrm{M} \mathrm{NaCl}$. The resulting solution was directly used for HPLC analytics. For complete loading $300 \mu \mathrm{l}$ of the solute were applied on the $200 \mu \mathrm{l}$ sample loop. This volume of solute produced reproducible data during calibration of the HPLC method.

\section{Proliferation Assays}

Proliferation assays were performed by incubation of 0.1 X $10^{6}$ mixed lymph node cells in a $100 \mu 1$ volume in 96-well microtiter plates. Activation was achieved by subsequent addition of soluble anti-CD3 mAb (clone $2 \mathrm{C} 11$ ) at a final dilution of $4 \mu \mathrm{g} / \mathrm{ml}$. Proliferation was analyzed by incubating cells for 72 hours during which $\left[{ }^{3} \mathrm{H}\right]$-thymidine $(0.4 \mu \mathrm{Ci})$ was included for the last 4 hours and collected with a cell harvester (Skatron, Sterling, VA, USA) onto glass fiber filters. Incorporated precursor was counted in a scintillation analyzer (Tri-Carb, Packard, Meriden, CT, USA). prior to activation by addition of anti-CD3 antibodies. Rp-8-BrcAMPS when used in vitro, was added at a final concentration of $1 \mathrm{mM}, 30 \mathrm{~min}$ prior to anti-CD3 $\mathrm{mAb}$. Stimulation indexes were individually determined for each mouse according to the formula : mean cpm in anti-CD3 stimulated cultures/ mean background cpm in unstimulated cultures.

\section{Statistical Analyses}

In Figs. $(\mathbf{1}, \mathbf{2})$, the data were displayed in Box-andWhisker plots which illustrate the spread of data groups around their medians. In this type of graph, the box indicates 25 to 75 percentiles whereas whiskers indicate 2.5 to 97.5 percentiles. Data quoted in the text correspond to means \pm sem. Unpaired two-tailed t tests were used for comparisons of different groups of animals. Paired t-tests were used to compare the effect of in vitro exposure to Rp-8-Br-cAMPS $v s$ PBS of the lymphocytes of non-treated infected mice. Statistical analyses were performed using GraphPad Prism 4 (GraphPad Software Inc., San Diego, CA) software package.

\section{Spleen}
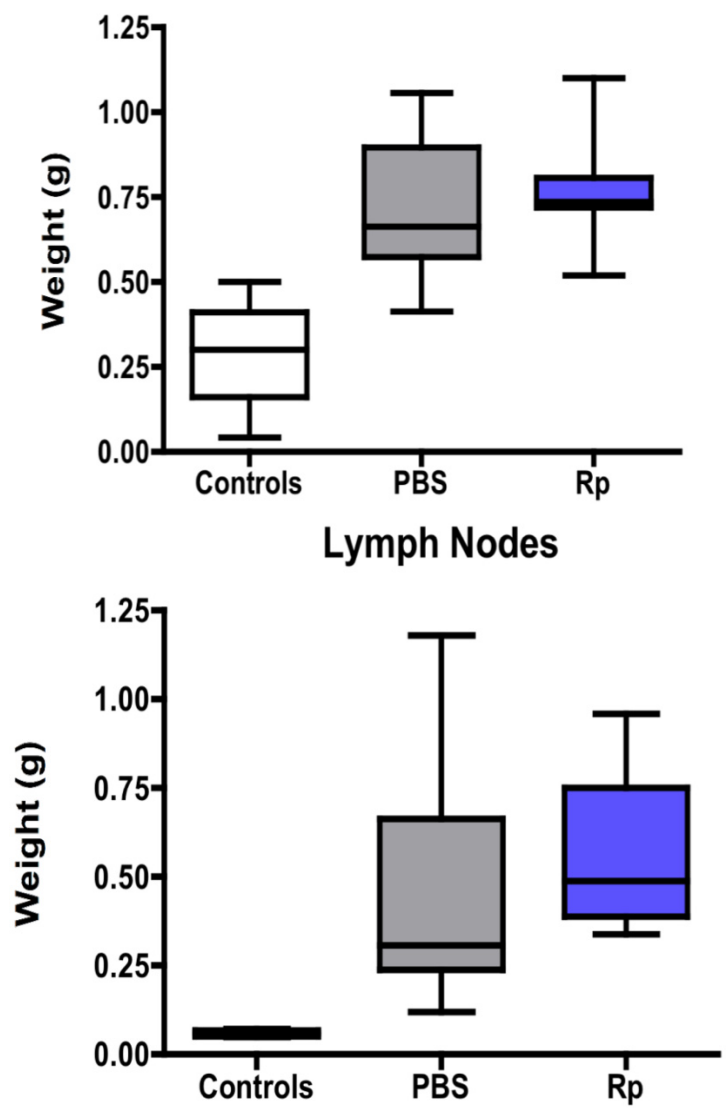

Fig. (1). Groups of MAIDS mice ( $n=8)$ were treated with $\mathrm{Rp}-8-\mathrm{Br}$ cAMPS or PBS for 10 days. After sacrificing the mice, spleens (upper panel) and peripheral and mesenteric lymph nodes from both sides of individual mice were pooled and weighted (lower panel) were. Box plots with median; 25-75\% (box) and 2.5--97.5\% (bar) percentiles for each group are shown. 


\section{RESULTS AND DISCUSSION}

Initial experiments were performed to evaluate the biodistribution of Rp-8-Br-cAMPS. The concentration of the compound was measured by HPLC on liver, spleen and plasma of the animals implanted with the osmotic pumps set to deliver $0.7 \mathrm{mg} \mathrm{Rp}-8-\mathrm{Br}-\mathrm{cAMPS} / 24 \mathrm{~h}$. As shown in Table 1, Rp-8-Br-cAMPS was found at significant concentration in all the organs analysed demonstrating that the compound was delivered to relevant tissues such as spleen. The toxicity of the Rp-8-Br-cAMPS was also evaluated and as shown in Table 2, there were no unscheduled deaths during the study. Furthermore, there were no clinical signs observed in the mice throughout the time of administration in the different experiments (Table 2). All animals were considered to have achieved satisfactory bodyweight gains through the study. Macroscopic examination at time of sacrifice of the animals did not reveal any abnormalities. Thus, we conclude that Rp-
8-Br-cAMPS was well tolerated in control non-infected animals as well as in infected mice.

In a next set of experiments performed with iterative injections of Rp-8-Br-cAMPS during 10 days, we evaluated the effects of the compound in mice with established RadLV-Rs infection. Typically, each experiment encompassed four groups of seven to ten mice (2 groups with mice inoculated with RadLV-Rs eight weeks earlier and 2 groups with age-matched sham-injected controls). Mice were treated either with Rp-8-Br-cAMPS for 10 days (daily intraperitoneal injections of $1 \mathrm{mg} / \mathrm{mouse}$ ) or equivalent sham-injections with $300 \mu \mathrm{l}$ PBS. At the end of the 10-days injection period, mice were sacrificed. Treatment with Rp-8-Br-cAMPS had no significant effect on the extent of lymphadenopathy and splenomegaly which is typical of RadLV-Rs retroviral infection. Indeed, weights of the lymphoid organs were always similar in infected mice treated with Rp-8-Br-cAMPS and in

Table 1. Biodistribution of the Rp-8-Br-cAMPS in Control and MAIDS Mice After In Vivo Treatment for 14 days with Alzet Pump Loaded with $10 \mathrm{mg}$ of Rp-8-Br-cAMPS. The Given Values for the Rp-8-Br-cAMPS Concentrations are the Mean from Duplicate to Triplicate HPLC Analytics

\begin{tabular}{|c|c|c|}
\hline MAIDS/Rp-8-Br-cAMPS (Sodium) in & Concentration (ng/g) & Concentration $\boldsymbol{\mu m o l} / \mathbf{k g})$ \\
\hline \hline Liver & $110 \mathrm{ng} / \mathrm{g}$ & $0.247 \mu \mathrm{mol} / \mathrm{kg}$ \\
\hline Spleen & $90 \mathrm{ng} / \mathrm{g}$ & $0.202 \mu \mathrm{mol} / \mathrm{kg}$ \\
\hline Serum & $100 \mathrm{ng} / \mathrm{ml}$ & $0.224 \mu \mathrm{mol} / \mathrm{kg}$ \\
\hline
\end{tabular}

\begin{tabular}{|c|c|c|}
\hline Control Mice/Rp-8-Br-cAMPS (Sodium) in & Concentration (ng/g) & Concentration $\boldsymbol{\mu m o l} / \mathbf{k g})$ \\
\hline \hline Liver & $50 \mathrm{ng} / \mathrm{g}$ & $0.112 \mu \mathrm{mol} / \mathrm{kg}$ \\
\hline Spleen & $40 \mathrm{ng} / \mathrm{g}$ & $0.09 \mu \mathrm{mol} / \mathrm{kg}$ \\
\hline Serum & $90 \mathrm{ng} / \mathrm{ml}$ & $0.202 \mu \mathrm{mol} / \mathrm{kg}$ \\
\hline
\end{tabular}

Table 2. Toxicity of the Rp-8-Br-cAMPS In Vivo in MAIDS and Control Mice

\begin{tabular}{|c|c|c|c|c|c|c|}
\hline Experiment & $\begin{array}{l}\text { Number of } \\
\text { Mice/Group }\end{array}$ & Mode of Administration & Rp-8-Br-cAMPs Dose/Mouse & $\begin{array}{c}\text { Duration of the } \\
\text { Treatment }\end{array}$ & Death & $\begin{array}{c}\text { Clinical Signs } \\
\text { of Toxicity }\end{array}$ \\
\hline \multirow{2}{*}{1} & 7 controls non infected & \multirow{2}{*}{ Alzet pumps implanted subcutanously } & $10 \mathrm{mg} /$ pump release $0.7 \mathrm{mg} / \mathrm{day}$ & \multirow{2}{*}{14 days } & 0 & \multirow[t]{2}{*}{ None } \\
\hline & 9 MAIDS & & $10 \mathrm{mg} /$ pump release $0.7 \mathrm{mg} /$ day & & 0 & \\
\hline \multirow{2}{*}{2} & 7 controls non infected & \multirow{2}{*}{ Alzet pumps implanted subcutanously } & $10 \mathrm{mg} /$ pump release $0.7 \mathrm{mg} /$ day & \multirow{2}{*}{14 days } & 0 & \multirow[t]{2}{*}{ None } \\
\hline & 9 MAIDS & & $10 \mathrm{mg} /$ pumprelease $0.7 \mathrm{mg} /$ day & & 0 & \\
\hline 3 & 9 MAIDS & i.p. & $30 \mathrm{mg} / \mathrm{kg} /$ day & 10 days & 2 & None \\
\hline \multirow{2}{*}{4} & 7 controls non infected & \multirow[t]{2}{*}{ i.p. } & $30 \mathrm{mg} / \mathrm{kg} /$ day & \multirow{2}{*}{10 days } & 0 & \multirow[t]{2}{*}{ None } \\
\hline & 7 MAIDS & & $30 \mathrm{mg} / \mathrm{kg} /$ day & & 0 & \\
\hline 5 & 7 controls non infected & i.p. & $30 \mathrm{mg} / \mathrm{kg} /$ day & 10 days & 0 & None \\
\hline \multirow{2}{*}{7} & 6 controls non infected & \multirow[t]{2}{*}{ i.p. } & $30 \mathrm{mg} / \mathrm{kg} /$ day & \multirow{2}{*}{10 days } & 0 & \multirow[t]{2}{*}{ None } \\
\hline & 7 MAIDS & & $30 \mathrm{mg} / \mathrm{kg} /$ day & & 0 & \\
\hline
\end{tabular}


infected mice receiving PBS (Fig. 1). Size, and cellularity were also similar in both groups (data not shown). After preparation of cell suspensions from the peripheral lymph nodes of each mouse from the different experimental groups, we measured the proliferative responses to soluble anti-CD3 $\mathrm{mAb}$. The cells were cultured for 72 hours in the presence of anti-CD3 $\mathrm{mAb}(2 \mathrm{C} 11: 4 \mu \mathrm{g} / \mathrm{ml})$. During this 72 -hour culture period, $\mathrm{Rp}$-8-Br-cAMPS (1 mM) was added to the cells isolated from mice treated with this compound. Administration of Rp-8-Br-cAMPS had no effect on the response to antiCD3 mAb in non-infected mice (not shown). As expected, in RadLV-Rs retrovirus-infected mice, proliferative responses to anti-CD3 mAb were nearly abolished, with stimulatory indexes (defined as stimulated/non stimulated CPMs) typically around $10 \%$ of values reached with the cells of normal mice (Fig. 2). Treatment of non-infected mice with Rp-8-BrcAMPS did not significantly modify their proliferative responses to the anti-CD3 mAb (not shown). In contrast, i.p. administration of the PKA type I inhibitor Rp-8-Br-cAMPS to RadLV-Rs infected mice strongly increased their responses to the anti-CD3 mAb $(31.97 \pm 4.21 \mathrm{n}=10$ vs $5.979 \pm$ $0.882 \mathrm{n}=8, \mathrm{p}<0.0001)$. In fact, stimulatory indexes values reached more than $50 \%$ of control values in most experiments (Fig. 2). When the cells of infected and treated mice were activated in vitro in the absence $\mathrm{Rp}-8$-Br-cAMPS, the effect of the treatment was partially lost and became non significant in certain experiments (not shown). When cells from untreated, retrovirus-infected mice were incubated in the presence of $\mathrm{Rp}-8$-Br-cAMPS in vitro, a significant improvement of $\mathrm{T}$ cell responses also occurred $(12.45 \pm 2.02$ $\mathrm{n}=8$ vs $5.98 \pm 0.88 \mathrm{n}=8)(\mathrm{p}=0.013)$ as demonstrated in our previous studies but stimulation index remained much lower than those of infected mice treated with IP injections of the compound $(\mathrm{p}=0.0014)$ demonstrating the in vivo impact of PKA type I inhibition on the restoration of proliferative responses in infected mice.

Despite its specific virological features and the preferential tropism of RadLV-Rs for B cells rather than CD4 T cells, MAIDS presents with striking similarities with HIV infection such as polyclonal and sustained immune activation involving CD4 as well as CD8 T cells and leading to the impairment of $\mathrm{T}$ cell responses. Indeed, recent evidence suggests that abnormal immune activation rather than direct cytopathic effects of HIV plays a major role in the pathogenesis of HIV infection, at least during its early stages. The $\mathrm{PGE}_{2}$-cAMP-PKA type I pathway is most probably involved in this abnormal activation, as shown by the reduction of activated CD8 CD38 T cells in HIV-infected patients treated with celecoxib [7] and by in vitro data demonstrating partial restoration of $\mathrm{T}$ cell responses after incubation with $\mathrm{Rp}-8 \mathrm{-Br}-$ cAMPS [1]. Although COX-2 is indeed overexpressed in HIV infection, it is likely that other soluble factors might play a role in the activation of adenylate cyclase. CCR5 plays a paramount importance in the pathogenesis of HIV infection and this could be partly independent of its function as an entry coreceptor for HIV [14]. Interestingly, HIV coreceptors such as CCR5 and CXCR4 are coupled to protein G and ligand binding activates adenylate cyclase. Gp120 binding to its coreceptor could therefore directly increase cAMP concentration by a $\mathrm{PGE}_{2}$-independent mechanism. It is therefore important to design pharmacological approaches acting downstream of adenylate cyclase activation.

\section{CONCLUSIONS}

This is the first report showing an improvement of immune function in a model of retroviral infection after a short

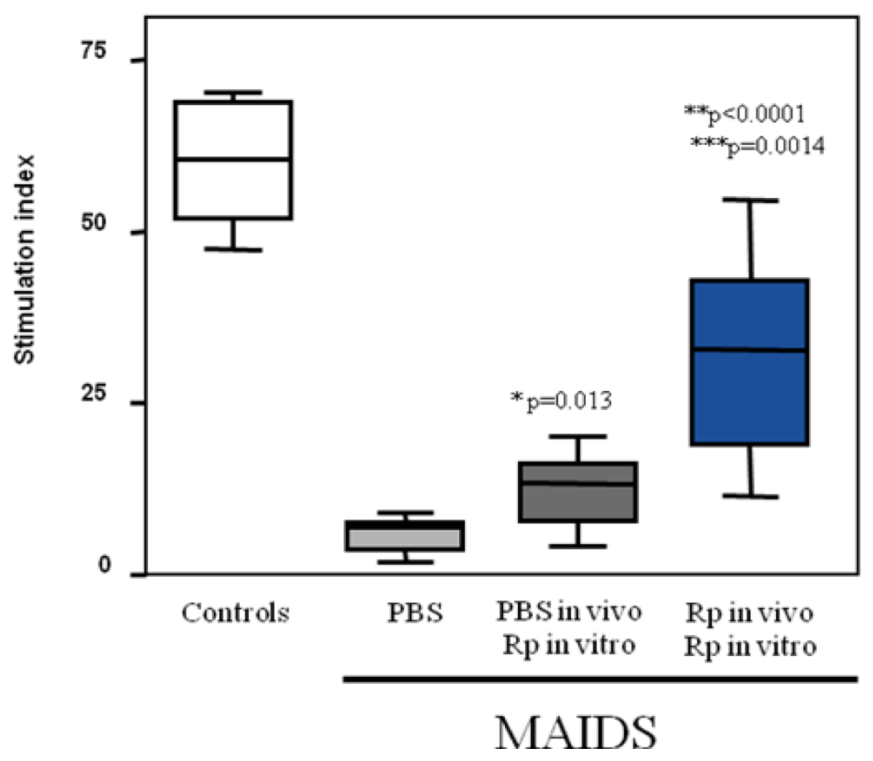

Fig. (2). Rp-8-Br-cAMPS in vivo treatment strongly increases antiCD3 induced proliferative responses of RadLV-Rs retrovirusinfected mice T-cells. Groups of infected mice (MAIDS) received PBS $(\mathrm{n}=8)$ or Rp-8-Br-cAMPS ( $1 \mathrm{mg} /$ day/mouse) ( $\mathrm{n}=10$ blue box) daily for 10 days, respectively. A group of control uninfected mice received PBS (white box). At the end of the 10-day treatment period, mice were sacrificed and mixed lymph node cells were cultured for $72 \mathrm{~h}$ in the presence of anti-CD3 mAb in which $\left[{ }^{3} \mathrm{H}\right]-$ thymidine was included for the last 4 hours. For MAIDS nontreated mice, a comparison was made between culture without $\mathrm{Rp}$ 8-BR-cAMPS (light grey box) vs culture with Rp-8-Br-cAMPS (dark grey box). The lymphocytes from treated mice were cultured in the presence of Rp-8-Br-cAMPS.

course parenteral administration of an inhibitor of PKA type I. Our observations provide proof-of-principle for reversal of retrovirus-induced immunodeficiency by a new class of pharmacological agents directly acting on proximal steps of $\mathrm{T}$ cell signalling. Further investigation is warranted to establish if PKA type I blockade also improves antigen-specific immune responses and other immune parameters such as CD4 cytokine secretion and CD8 functions in the infected mice.

\section{ACKNOWLEDGEMENTS}

This work was supported by a CRAFT grant (contract no. QLK2-CT-2002-72419) from the European Commission coordinated by Lauras AS and with the University of Liège, the University of Oslo and BioLog Gmbh among the partners.

\section{REFERENCES}

[1] Aandahl EM, Aukrust P, Skalhegg BS, et al. Protein kinase A type I antagonist restores immune responses of $\mathrm{T}$ cells from HIVinfected patients. FASEB J 1198; 12: 855-862.

[2] Tasken K, Ruppelt A. Negative regulation of T-cell receptor activation by the cAMP-PKA-Csk signalling pathway in T-cell lipid rafts. Front Biosci 2006; 11: 2929-2939.

[3] Aukrust P, Aandahl EM, Skalhegg BS, et al. Increased activation of protein kinase A type I contributes to the $\mathrm{T}$ cell deficiency in 
common variable immunodeficiency. J Immunol 1999; 162: 11781185 .

[4] Johansson CC, Bryn T, Aandahl EM, et al. Treatment with type-2 selective and non-selective cyclooxygenase inhibitors improves Tcell proliferation in HIV-infected patients on highly active antiretroviral therapy. AIDS 2004; 18: 951-952.

[5] Torgersen KM, Vang T, Abrahamsen H, Yaqub S, Tasken K. Molecular mechanisms for protein kinase A-mediated modulation of immune function. Cell Signal 2002; 14: 1-9.

[6] Gjertsen BT, Mellgren G, Otten A, et al. Novel (Rp)-cAMPS analogs as tools for inhibition of cAMP-kinase in cell culture. Basal cAMP-kinase activity modulates interleukin-1 beta action. J Biol Chem 1995; 270: 20599-20607.

[7] Kvale D, Ormaasen V, Kran AM, et al. Immune modulatory effects of cyclooxygenase type 2 inhibitors in HIV patients on combination antiretroviral treatment. AIDS 2006; 20: 813-820.

[8] Rahmouni S, Aandahl EM, Trebak M, Boniver J, Tasken K, Moutschen M. Increased cAMP levels and protein kinase (PKA) type I activation in CD4+ T cells and B cells contribute to retrovirus-induced immunodeficiency of mice (MAIDS): a useful in vivo model for drug testing. FASEB J 2001; 15: 1466-1468.

[9] Kyttaris VC, Wang Y, Juang YT, Weinstein A, Tsokos GC. CAMP response element modulator a expression in patients with systemic lupus erythematosus. Lupus 2006; 15(12): 840-4.
[10] Morse HC III, Chattopadhyay SK, Makino M, Fredrickson TN, Hugin AW, Hartley JW. Retrovirus-induced immunodeficiency in the mouse: MAIDS as a model for AIDS. AIDS 1992; 6: 607-621.

[11] Aandahl EM, Moretto WJ, Haslett PA, et al. Inhibition of antigenspecific $\mathrm{T}$ cell proliferation and cytokine production by protein kinase A type I. J Immunol 2002; 169: 802-808.

[12] Skalhegg BS, Landmark BF, Doskeland SO, Hansson V, Lea T, Jahnsen T. Cyclic AMP-dependent protein kinase type I mediates the inhibitory effects of 3 ',5'-cyclic adenosine monophosphate on cell replication in human T lymphocytes. J Biol Chem 1992; 267: 15707-15714.

[13] Rowe WP, Pugh WE, Hartley JW. Plaque assay techniques for murine leukemia viruses. Virology 1970; 42:1136-1139.

[14] Rahmouni S, Aandahl EM, Nayjib B, et al. Cyclo-oxygenase type 2-dependent prostaglandin E2 secretion is involved in retrovirusinduced T-cell dysfunction in mice. Biochem J 2004; 384(Pt 3): 469-76.

[15] Dolan MJ, Kulkarni H, Camargo JF, et al. CCL3L1 and CCR5 influence cell-mediated immunity and affect HIV-AIDS pathogenesis via viral entry-independent mechanisms. Nat Immunol 2007; 8(12): 1324-36.

[16] Collado-Hidalgo A, Sung C, Cole S. Adrenergic inhibition of innate anti-viral response: PKA blockade of Type I interferon gene transcription mediates catecholamine support for HIV-1 replication. Brain Behav Immun 2006; 20: 552-563. 